\title{
What about money? \\ Earnings, household financial organization, and housework
}

\author{
Yang Hu \\ Department of Sociology, Lancaster University, UK \\ ORCID: 0000-0003-2027-8491 \\ E-mail: yang.hu@lancaster.ac.uk
}

Address: Department of Sociology, Bowland North, Bailrigg, Lancaster LA1 4YN, UK

\section{Acknowledgements}

An earlier version of this article was presented at the 2018 Conference of the Work Family Researchers Network in Washington DC, USA. The author is grateful for the helpful comments received at the conference. The UK Household Longitudinal Study is an initiative funded by the Economic and Social Research Council and various government departments, with scientific leadership by the Institute for Social and Economic Research, University of Essex, and survey delivery by NatCen Social Research and Kantar Public. The research data are distributed by the UK Data Service. The author is solely responsible for all analyses and interpretations of the data. 


\begin{abstract}
Objective: This research investigates the role played by household financial organization in configuring the housework participation of women and men and in moderating the influence of earnings on housework.
\end{abstract}

Background: Existing research has focused on the ways in which earnings shape gendered power and housework performance in couple relationships. However, no research has examined how household financial organization intervenes between the receipt of earnings in the labor market and the performance of housework at home.

Method: Two-stage least squares regressions were used to analyze data from Waves 2 and 4 of the United Kingdom Household Longitudinal Study ( $N=6,070$ couples).

Results: Management of household finances is associated with an increase in housework time for both men and women, whereas control of household financial decisions reduces men's but not women's housework time. Women's individual earnings reduce their housework time only when they can access these earnings. Supporting both resource bargaining theory and gendered resources theory, men's relative earnings reduce their housework time when they or their partners manage the couple's earnings, but not when partners manage their earnings independently. Women's individual earnings and men's relative earnings reduce their housework time only when they have partial or full control of household financial decisions.

Conclusion: The management and control of household finances influence the time spent by women and men on housework in ways distinct from yet equally as important as those of earnings. Household financial organization is a key premise moderating when and how gender equality in the public sphere helps promulgate gender equality at home.

Keywords: Gender, Housework, Inequalities, Marital Power, Money Management, TwoStage Least Squares Regression. 
The unequal division of housework tells of marital power in couple relationships and it remains a highly contested area of the ongoing gender revolution (Davis \& Greenstein, 2013). Despite considerable progress toward gender equality in education and the labor market (Gerson, 2009), women in many countries still spend substantially more time on housework than their male counterparts (Altintas \& Sullivan, 2016; Hu \& Yucel, 2018). The relationship between money and gendered housework participation has attracted particular attention from scholars (Bittman, England, Sayer, Folbre, \& Matheson, 2003; Carlson \& Lynch, 2017; Chesley \& Flood, 2017; Gupta, 2006, 2007; Kan, 2008; Killewald, 2011). Money underpins the complex organization of social relations within and between the public and domestic spheres (Palh, 1990; 1995). It reflects and informs the unequal distribution of power between the sexes (Becker, 1991; Bianchi, Sayer, Milkie, \& Robinson, 2012; Vogler, 1998, 2005). Against this backdrop, money provides a pertinent lens for examining why gender equality in the public sphere does or does not help promulgate gender-equal housework participation at home.

Building on the tradition of resources and marital power (Blood \& Wolfe, 1960; Rodman, 1972), existing theories—notably resource bargaining (Brines, 1994; Lundberg \& Pollak, 1996), gendered resources (Tichenor, 1999; Zuo \& Bian, 2001), and individual autonomy (Gupta, 2006, 2007) — have fertilized a growing body of research on the impact of money on gendered housework performance. Nevertheless, existing research has been limited by a tendency to focus on the generation of earnings (Bittman et al., 2003; Gupta, 2007; Kan, 2008; Killewald, 2011), with scarce attention to the organization of household finances. Nearly three decades after Pahl's (1989) ground-breaking study of household financial organization and its implications for conjugal power, intra-household economy remains a "black box" in research on gendered housework participation. If money embodies power (Gupta, 2007; Pahl, 1989; Zelizer, 1994), household financial organization - the management 
of earnings and control of financial decisions — is key to a full understanding of how such power is distributed and operates between partners (Bennett, 2013; Pahl, 1990, 1995; Vogler, 1998, 2005; Yodanis \& Lauer, 2007).

To remedy the above limitation and to provide a full understanding of the relationship between money, marital power and housework, this study theorizes and empirically tests the role played by household financial organization - i.e., financial management and decision making — in shaping the housework time of women and men and in moderating the influence of individual and relative earnings on housework. To account for potential reciprocal relationships between money and housework (Carlson \& Lynch, 2017), specifically the possibility that housework also shapes market earnings (Cooke \& Hook, 2018), I use instrumental variables two-stage least squares (2SLS) models to aid causal identification. The empirical analysis draws on data from Waves 2 (2010-2012) and 4 (2012-2014) of the United Kingdom Household Longitudinal Study (UKHLS, www.understanding society.ac.uk). The findings call into question the taken-for-granted link between earnings and housework. I underline the role played by financial organization, over and above earnings, in shaping the time spent by women and men on housework. I show that financial organization is a crucial premise conditioning when and how individual and relative earnings influence the housework participation of women and men. The findings refine resource theories and contribute to the marital power literature by uncovering the gendered ways in which the generation and mobilization of resources jointly configure power between partners.

\section{THEORETICAL CONSIDERATIONS}

\section{Money and Housework: Household Financial Organization as the Missing Link}

Research on the relationship between money and housework has tended to consider money as a unidimensional construct, in terms of earnings or wage (Bittman et al., 2003; Carlson \& Lynch, 2017; Gupta, 2007; Kan, 2008; Killewald, 2011). A separate line of scholarship has 
emphasized the importance of control of resources and decision-making authority in shaping marital power (Blood \& Wolfe, 1960; Lundberg \& Pollak, 1996; Pepin, 2019; Rodman, 1972; Tichenor, 1999), which is crucial to the negotiation of domestic labor division (Bianchi et al., 2012). Nevertheless, how intra-household financial organization influences partners' housework participation remains an open empirical question. Partners' decision to pool their earnings or to maintain financial independence and their control of household financial decisions tell of the checks and balances of power between partners (Pahl, 1990; Pepin, 2019; Tichenor, 1999; Yodanis \& Lauer, 2007). Vogler (1998, p. 691) argued that "the ways in which couples organize money within the family has an independent effect on power, over and above the resources each person contributes." Financial organization also serves as a major medium through which money "talks" in couple relationships (Pahl, 1989, 1990; Vogler, 2005), and may thus moderate when and how earnings translate into power (Bennett, 2013; Pahl, 1995).

Two crucial processes intervene between partners' receipt of earnings in the labor market and the intra-household inequalities resulting from these earnings (Bennett, 2013). The first is partners' management of earnings (Pahl, 1995; Pepin, 2019; Vogler, 1998). Three major systems of financial management exist (Bisdee, Daly, \& Price, 2013; Pahl, 1990; Vogler, 2005): pooling, whole-wage, and independent. In the pooling system, partners share most or all of their earnings. This system often reflects partners' interdependence (Kenney, 2006; Pahl, 1990, 1995). Although both partners have access to a joint pool of earnings, their differentiated contributions to the pool may become a source of unequal bargaining power (Bennett, 2013). In the whole-wage system, one partner takes charge of the family's finances and the other hands over his or her earnings, retaining only a small amount of personal spending money or a housekeeping allowance (Bisdee et al., 2013; Vogler, 1998). Due to their restricted nature, personal spending money and housekeeping allowances often reflect a 
lack of power and a sense of deprivation in couple relationships (Yodanis \& Lauer, 2007). In the independent system, partners retain their respective earnings, sometimes pooling a small portion to establish a joint housekeeping allowance (Ashby \& Burgoyne, 2009; Pahl, 1995). Within this system, each partner is usually economically self-sufficient (Vogler, 2005), resulting in a low level of interdependence between partners (Ashby \& Burgoyne, 2009).

Second, as the value of money is projected through its potential use (Himmelweit, Santos, Sevilla, \& Sofer, 2013; Zelizer, 1994), control of financial decisions constitutes another key dimension of household financial organization. Having a say in household financial decisions reflects one's control of money (Himmelweit et al., 2013), which may confer individuals with marital power and facilitate one's mobilization of money in the negotiation of domestic arrangements (Kenney, 2006; Rodman, 1972; Vogler, 1998). Partners who make joint financial decisions tend to have equal opportunities to derive power from the couple's earnings (Himmelweit et al., 2013; Vogler, 2005), although the level of power each can derive may still be influenced by his or her relative contribution to the couple's income (Kenney, 2006; Pahl, 1989; Vogler, 1998). Conversely, a lack of control of household financial decisions reflects not only a compromised bargaining position, but also limited capability to derive power from earnings (Bennett, 2013).

\section{Resource Bargaining Theory}

From the social exchange perspective (Blood \& Wolfe, 1960), family interactions are analogous to socio-economic exchanges in a marketplace (Becker, 1991). Specifically, resource bargaining theory postulates that partners' differentiated participation in paid labor confers greater power on the partner with higher earnings to "bargain out" of housework (Becker, 1991; Blood \& Wolfe, 1960; Brines, 1994). Bargaining power derived from relative earnings is constructed largely in the shadow of union dissolution (Bittman et al., 2003): a partner who is economically dependent on the other may be less able to support himself or 
herself and thus more vulnerable in the event of separation (Lundberg \& Pollak, 1996). Against this backdrop, managing the household's finances may help to mitigate the perception of precarity by fostering a sense of financial security (Pahl, 1989, 1990). Although some scholars have argued that physically taking hold of the couple's earnings may enable one to access a more favorable bargaining position (Himmelweit, 2013), others have expressed doubt as to the extent to which financial management directly confers bargaining power (Pahl, 1995; Vogler, 1998). If one partner is able to derive bargaining power from managing the couple's earnings, household financial management will reduce that partner's housework time, as stated in Hypothesis 1A. In addition, research has clearly shown that control of household financial decisions both results from and reflects the possession of bargaining power (Himmelweit et al., 2013; Pahl, 1989, 1991, 1995; Vogler, 1998, 2005), which may help reduce one's housework time, as specified in Hypothesis 1B.

Hypothesis 1A: Management of the couple's earnings reduces one's housework time. Hypothesis 1B: Control of household financial decisions reduces one's housework time.

The management of the couple's earnings and control of household financial decisions may bolster the influence of relative earnings on housework by reinforcing the dominant bargaining position of major earners (Pahl, 1995; Yodanis \& Lauer, 2007). Conversely, a lack of management and control of household finances may undermine the bargaining position derived from relative earnings (Pahl, 1989; Vogler, 2005). As dependence between partners is a key premise of resource bargaining theory (Becker, 1991), it may be impossible to derive bargaining power from relative earnings when little exchange occurs between partners. Focusing on British couples, Pahl $(1989,1995)$ and Vogler $(2005)$ found that partners who managed their finances independently tended to be economically self-sufficient, and that their lack of interdependence rendered them less susceptible to the 
threat of union dissolution. Therefore, the management of household finances and the control of financial decisions, respectively, may moderate the influence of relative earnings on housework, as specified in Hypotheses 1C and 1D.

Hypothesis 1C: Relative earnings reduce individuals' housework time when they manage all or part of the couple's earnings, but not when their partners manage the couple's earnings or partners manage their earnings independently.

Hypothesis 1D: Relative earnings have a greater effect in reducing individuals' housework time when they have greater control of household financial decisions.

\section{Gendered Resources Theory}

Compared with resource bargaining theory, gendered resources theory offers a more optimistic view of couple relationships. Instead of highlighting the possibility of union dissolution, it underlines the contribution of resource exchange between partners to the solidarity of couple units (Tichenor, 1999; Zuo \& Bian, 2001). Specifically, the notion of gender specialization posits that men and women are channeled into paid and unpaid work (Becker, 1991) and bound together by the provision of distinctive gender resources (e.g., earnings or domestic work) to maximize the utility of the unitary couple unit (Bennett, 1993; Tichenor, 1999). Although both gendered resources theory and resource bargaining theory postulate that relative earnings reduce one's housework participation, their underlying assumptions are substantively different. Whereas competition for control is central to the generation of bargaining power, gendered resources theory underlines the ethos of cooperation between partners (Zuo \& Bian, 2001).

The responsibility for financial management may be exchanged as a gendered task (Bennett, 2013; Vogler, 1998, 2005). The everyday management of household finances, such as settling bills and keeping bank accounts in check, is a chore that takes time in itself. Balancing the books and making ends meet often entail one's direct involvement in 
consumption activities such as grocery shopping (Vogler, 1998, 2005). Additionally, financial management, particularly among women, often correlates with the performance of other routine housework tasks (Bisdee et al., 2013; Yodanis \& Lauer, 2007). As a result, breadwinners sometimes strategically offload financial management onto their housekeeping partners (Pahl, 1990). Thus, the management of a couple's earnings may increase rather than reduce one's housework time (Pahl, 1990, 1995; Vogler, 1998), as specified in Hypothesis 2A (vs. 1A).

Hypothesis $2 A$ : Individuals spend more time on housework when they manage the couple's earnings, compared with when their partners manage part or all of the couple's earnings.

Financial management is a crucial medium for the exchange of gendered resources (Becker, 1991; Bennett, 2013; Vogler, 1998, 2005). As earners hand over their market earnings to their partners, the partners validate the contract of exchange by performing unpaid domestic labor in return (Zuo \& Bian, 2001). The exchange fosters a sense of cohesion and perceived fairness in couple relationships (Hu \& Yucel, 2018; Tichenor, 1999). In contrast to the resource bargaining argument that one seizes power by managing the couple's earnings, the transfer of earnings between partners may enable earners to "exchange out" (rather than "bargain out") of housework (Tichenor, 1999; Zuo \& Bian, 2001). If gendered resources theory holds true, earnings may have little exchange value when partners manage their earnings independently (Zuo \& Bian, 2001). These considerations lead to Hypothesis 2B.

Hypothesis 2B: Relative earnings reduce one's housework time when one's partner manages part or all of the couple's earnings, but not when one manages all of the couple's earnings or partners manage their earnings independently. 
However, gendered resources theory may not similarly apply to control of financial decisions, as prior research has shown that individuals lose rather than gain power when they relinquish control of financial decisions (Bennett, 2013; Himmelweit et al., 2013; Vogler, 2005), which concurs with the prediction derived from resource bargaining theory discussed in the previous section.

\section{Autonomy Theory}

Autonomy theory posits that partners' social behaviors may be driven by individual interests rather than by the couple's communal benefits, particularly given the rise of individualism and decline of familism (Beck \& Beck-Gersheim, 2002). Irrespective of their partners' earnings, therefore, individuals may be able to derive autonomous power from their own earnings (Gupta, 2006, 2007). The negative association between individual earnings and housework participation has received empirical support in recent studies of women (Gupta, 2006, 2007; Killewald \& Gough, 2010; Usdansky \& Parker, 2011). Two mechanisms underpin autonomy theory: "buying out" and "opting out" (Killewald, 2011). The former suggests that market earnings can be used to purchase substitute services such as domestic outsourcing (Carlson \& Lynch, 2017; Killewald, 2011). The latter suggests that individuals do not necessarily replace their domestic responsibilities; high earners may simply forgo housework if they deem the economic returns to domestic work to be less favorable than those to paid work (Killewald, 2011). High earners may also create less domestic demand as they spend less time at home (Gupta, 2007).

The implicit assumption of autonomy theory is that individuals have access to their own earnings (Gupta, 2006; Killewald, 2011). Highly individualized partners are more likely to manage their finances independently than to jointly manage household finances or relinquish the management of earnings to their partners (Vogler, 2005). The additional sense of autonomy derived from independent financial management, over and above the effect of 
individual earnings, may help to reduce individuals' housework time (Vogler, 1998, 2005), as specified in Hypothesis 3A.

Hypothesis $3 A$ : Individuals spend less time on housework when they manage their earnings independently, compared with when their partners manage part or all of the couple's earnings.

Meanwhile, earners may not be able to "buy out" or "opt out" of housework if they have no or limited access to their own earnings or little say in household financial decisions, however much they earn (Pahl, 1995). Therefore, individual earnings may confer autonomous power only when individuals can access and mobilize their earnings and control household financial decisions (Vogler, 1998, 2005). We thus expect the distinct modes of financial management and decision making, respectively, to moderate the influence of individual earnings on one's housework time, as specified in Hypotheses 3B and 3C.

Hypothesis 3B: Individual earnings have a greater effect in reducing one's housework time when one manages part or all of one's earnings, compared with when one's partner manages one's earnings.

Hypothesis 3C: Individual earnings have a greater effect in reducing one's housework time when one has greater control of household financial decisions.

\section{Gender Difference}

We have good reason to expect that women and men mobilize money in different ways to derive power and negotiate their housework participation. In the last few decades, women's increasing participation in the labor force and the detraditionalization of gender ideologies, particularly in Western developed countries, have given them a greater sense of individual autonomy (Beck \& Beck-Gernsheim, 2002; Gerson, 2009; Gupta, 2006, 2007; Killewald, 2011; Scott et al., 2010). In contrast, due to their "lagged adaption" to women's new gender roles, many men are still seen to hold on to the exchange model of gender specialization 
(Brines, 1994; Bittman et al., 2003; Carlson \& Lynch, 2017; England, 2010; Kan, 2008). As the social exchange model underscores the (gendered) division of paid and unpaid labor (Becker, 1991) and men still enjoy more favorable positions (e.g., higher wages) and opportunities (e.g., upward occupational mobility) than women in the labor market (England, 2010; Gerson, 2009), men are likely to seek an advantageous bargaining position by relying on the social exchange models of resource bargaining and gendered resources, whereas women are likely to mobilize individual autonomy to maximize their own interests.

\section{METHOD}

\section{Data and Sample}

The analysis drew on data from Waves 2 and 4 of the adult panel of the UKHLS, which were conducted from 2010 to 2012 and 2012 to 2014 respectively (Knies, 2016). The UKHLS is particularly suited to this research because it provides rich information on time use, earnings, and household financial organization. Only two waves were used, because key variables such as housework time, gender ideology, and financial decision making were measured only in Waves 2 and 4, and financial management was measured only in Wave 4. As the UKHLS incorporated sample members originally from the preceding British Household Panel Survey and over-sampled ethnic minorities as part of an ethnic boost, sampling and design weights were used throughout the analysis (Knies, 2016).

The analytical sample was first limited to continuously cohabiting or married heterosexual couples from Waves 2 and 4 in which both partners were of prime working age (20-59) - i.e., older than 19 at Wave 2 and younger than 60 at Wave 4 ( $n=7,717$ couples). Although computer-assisted personal interviews were the major mode of data collection in the UKHLS, sensitive information on issues such as household financial organization and gender ideology was collected via a self-completion module to minimize social desirability bias. As only a representative subsample took the self-completion module, the eligible 
sample was then restricted to 6,423 couples. A further 353 couples were excluded because one or both partners had provided missing or invalid information on key variables such as housework time, earnings, or financial organization. The results of Little's missingcompletely-at-random test confirmed the randomness of the list-wise deletion of the 353 couples (Li, 2013). The final analytical sample comprised 6,070 couples, as described in Table 1. For simplicity, I refer to Waves 2 and 4 of the survey as T1 and T2 hereafter.

[Insert Table 1 Here]

\section{Analytical Approach}

The key analytical aim was to examine the influence of money-earnings, financial organization, and their interaction —on the housework participation of male and female partners. However, it was also important to account for the potential reciprocal relationship between earnings and housework (Carlson \& Lynch, 2017). Following the human capital perspective (Becker, 1991), scholars have found that housework participation may negatively influence one's earnings in the labor market (Cooke \& Hook, 2018). If so, ordinary least squares regression may depress standard error, increasing susceptibility to Type I error (Carlson \& Lynch, 2013, 2017). Although fixed-effects panel regression with lagged variables accounts for unobserved endogeneity, the limited number of suitable waves of data rendered the fixed-effects approach implausible (Bollen, 2012).

To account for unobserved endogeneity and reverse causality, I used the instrumental variables 2SLS modeling approach (Bollen, 2012). The models were built on four sets of variables (Bollen, 2012): (1) outcome variables (housework time of women and men $\left.\left[H W_{T 2}\right]\right) ;(2)$ endogenous variables (individual earnings $\left[I E_{T 2}^{\text {Observed }}\right]$ and relative earnings $\left.\left[R E_{T 2}^{\text {Observed }}\right]\right)$; (3) instrumental variables (IV); and (4) exogenous variables, including financial organization measures $\left(\mathrm{FO}_{T 2}\right)$ and covariates $(\mathrm{CV})$. The first stage involved regressing each endogenous variable on the IVs and covariates. With the presence 
of two endogenous variables, two first-stage models were estimated, as specified in Equations (1) and (2). In the second stage, individuals' weekly housework time at T2 was regressed on the predicted values of the endogenous variables ( $I E_{T 2}^{\text {Estimated }}$ and $\left.R E_{T 2}^{\text {Estimated }}\right)$ from the first stage and the exogenous variables, as specified in Equation (3).

$$
\begin{aligned}
& I E_{T 2}^{\text {Observed }}=\beta_{1} I V+\beta_{2} C V+\alpha_{1}+\varepsilon_{1} \\
& R E_{T 2}^{\text {Observed }}=\beta_{3} I V+\beta_{4} C V+\alpha_{2}+\varepsilon_{2} \\
& H W_{T 2}=\beta_{5} I E_{T 2}^{\text {Estimated }}+\beta_{6} R E_{T 2}^{\text {Estimated }}+\beta_{7} F O_{T 2}+\beta_{8} F O_{c v}+\alpha_{3}+\varepsilon_{3}
\end{aligned}
$$

The IV 2SLS models were estimated using the "ivreg2" function in Stata (Baum, Schaffer, \& Stillman, 2010), which allowed the three equations to be estimated jointly to obtain corrected standard errors. The models were built in three steps for women (Model A) and men (Model B) separately. Model 1 included the main effects of all of the variables. In Model 2, separate slopes for individual earnings and relative earnings were estimated for distinct modes of financial management. In Model 3, separate slopes for the earnings variables were estimated for different modes of financial decision making.

\section{Weekly Housework Time}

The survey asked the respondents to report the time they spent per week on routine housework at T2, including chores such as cooking, cleaning, laundry, ironing, and grocery shopping, but excluding care provision. Although this stylized measure may be less accurate than time-diary measures, Kan and Pudney (2008) found that the associated report errors were largely random. The measure was top-coded at the $99^{\text {th }}$ percentile to minimize the influence of outlier cases. On average, women $(M=14.08)$ spent more than twice as much time than men $(M=6.05)$ on housework $(t=60.74, p<.001)$, mirroring the statistics $\left(M_{\text {women }}\right.$ $\left.=14.23, M_{\mathrm{men}}=5.60\right)$ obtained from time-diary data in the UK (Altintas \& Sullivan, 2016).

Endogenous Variables: Individual and Relative Earnings 
The survey measured individuals' monthly gross income in British pounds. Whereas net income may vary according to pension and tax arrangements, gross income comprehensively measures individuals' socio-economic standing and earning power. To account for its skew distribution, the measure was top-coded at the $99^{\text {th }}$ percentile and log-transformed in all of the statistical models. The average monthly gross income of men $\left(M_{\mathrm{T} 1}=£ 2,620\right.$, median $=$ $£ 2,190 ; M_{\mathrm{T} 2}=£ 2,710$, median $\left.=£ 2,280\right)$ was considerably higher than that of women $\left(M_{\mathrm{T} 1}=\right.$ $£ 1,530$, median $=£ 1,300 ; M_{\mathrm{T} 2}=£ 1,540$, median $=£ 1,310 ; t_{\mathrm{T} 1}=38.37, t_{\mathrm{T} 2}=39.34, p<.001$ for both). One's relative earnings were calculated as the proportion of the couple's total earnings represented by individual earnings. An average man in the UK contributed around $60 \%$ of his couple's gross income at both $\mathrm{T} 1$ and $\mathrm{T} 2$.

\section{Household Financial Organization}

In a self-completion module, individual respondents were asked to describe the management of the household finances between partners only at T2. The response categories were as follows: (1) "we share and manage our household finances jointly"; (2) "I look after the household's money except my partner's spending money”; (3) “my partner is given a housekeeping allowance; I look after the rest of the money"; (4) "my partner looks after all of the household's money except my personal spending money"; (5) "I am given a housekeeping allowance; my partner looks after the rest of the money"; (6) "we pool some of the money and keep the rest separate"; (7) "we keep our finances completely separate"; and (8) "I have some other arrangement". I deleted a small number of couples (some of the 353 couples eliminated during data cleaning) in which one or both partners had other financial arrangements. As the housekeeping allowance and personal spending money systems, which indicate a lack of control over family finances (Pahl, 1989; 1995), accounted for fewer than $4 \%$ of the cases, I recoded the original categories into four groups: pooling $(1 ; 48 \%$ for both women and men); female whole-wage (women reported 2 and 3, 23\%; men reported 4 and 5, 
24\%); male whole-wage (women reported 4 and 5, 17\%; men reported 2 and 3, 18\%); and independent ( 6 and $7 ; 12 \%$ of women and $10 \%$ of men).

The respondents were also asked to indicate who had the say in their households' financial decisions. The responses were recorded using four categories: (1) "the respondent", (2) “the respondent's partner/spouse”, (3) "both partners/spouses have equal say", and (4) "other". After eliminating couples who had chosen the "other" option (17 of the 353 couples eliminated by listwise deletion during data cleaning), the original categories were recoded as "female control" (1 for women, 15\%; 2 for men, 12\%), "joint control" (3 for both women, $68 \%$, and men, $70 \%$ ), and "male control" ( 2 for women, $17 \%$; 1 for men, $18 \%$ ).

\section{Instrumental Variables}

When analyzing panel data, it is common to use lagged measures as IVs (Bollen, 2012). In this research, the measures of individual and relative earnings at T1 were included as IVs for individual and relative earnings at T2. Lagged variables satisfy the first requirement of IVs, as they are associated with corresponding endogenous variables (Bollen, 2012). However, it is unclear whether they also satisfy the second requirement of IVs: to be uncorrelated with the error term of the equation. Therefore, informed by previous research (Cunningham, 2001a, 2001b), I also included parents' education as an additional IV for individual and relative earnings at $\mathrm{T} 2$. The variable was taken temporally prior to the endogenous variables, and it captured the highest education qualification achieved by the mother or the father, whichever was higher, using four categories: "no qualification" (47\% for both genders), "school diploma" (19\% for women; $20 \%$ for men), "post-school qualification" ( $23 \%$ for both genders), and "university degree or higher" (11\% for women; $10 \%$ for men). Three tests were conducted (Bollen, 2012; Carlson \& Lynch, 2017), which confirmed the adequacy of the IVs (see the findings section for test results): (1) the Anderson canonical correlation likelihood ratio (CCLR) test supported the relevance of the IVs; (2) the Hansen-Sargan test confirmed 
that the IVs were uncorrelated with the error term; and (3) the Cragg-Donald test showed that the IVs strongly identified the models. Other IVs such as self-employment and homeownership were used in previous research (Carlson \& Lynch, 2013, 2017), but they did not pass all of the three tests to qualify as adequate IVs in this research.

\section{Covariates}

The respondents' age was included as a linear regressor, as earlier tests have shown this to be the most parsimonious solution. At T2, the women averaged $43.22(S D=9.87)$ and the men averaged $45.23(S D=9.73)$ years old $(t=35.40, p<.001)$. I included dummy variables for one's own and one's partner's ethnic minority status (7\% for both genders; Kan \& Laurie, 2016). I took account of whether the respondents and their partners, respectively, had obtained a degree after high school. A larger proportion of the women $(40 \%)$ than the men $(36 \%)$ were degree holders $\left(\chi^{2}=9.28, p<.01\right)$. Each partner's weekly paid work time was measured and calculated in the same way as their housework time. On average, the women spent 20.77 hours and the men spent 28.82 hours on paid work per week $(t=30.68, p<.001)$. As poor health limits one's ability to perform housework, I controlled for the respondents' and their partners' self-reported health, recorded on a 5-point scale ranging from (1) "good" to (5) "poor". The scale was reversed so that a higher score indicated a better state of selfperceived health.

I also controlled for the respondents' gender ideology. The respondents were asked to report on a 5-point scale, ranging from (1) "strongly agree" to (5) "strongly disagree", the extent to which they agreed with the following statements: "a pre-school child is likely to suffer if his or her mother works," "all in all, family life suffers when the woman has a fulltime job," "both the husband and the wife should contribute to the household income," and "a husband's job is to earn money; a wife's job is to look after the home and family." I reversed the scales so that a higher score indicated a more egalitarian gender ideology. Factor 
analysis - Varimax rotation and the Bartlett method - was used to extract the gender ideology index, which formed a single factor with an eigenvalue of 1.66 and a Cronbach's $\alpha$ of 0.66 .

At the couple level, I distinguished between unmarried cohabiting and married couples $(83 \%)$. The presence of children may increase housework demand. I thus controlled for the number of children younger than 16 in the household, using a categorical variable: "none" (48\%), "one" (20\%), "two" (22\%), and "three and above" (10\%). I also controlled for the age of the youngest child in the household. The use of domestic outsourcing was captured using a dummy variable indicating whether a couple used third-party help with routine chores such as grocery shopping, cooking, housekeeping and laundry (4\%). Apart from age, marital status, ethnicity, self-reported health, information on children and domestic outsourcing, which were measured at $\mathrm{T} 2$, lagged $\mathrm{T} 1$ measures were used for the other covariates to account for potential reversal in causality (Carlson \& Lynch, 2013, 2017).

\section{FINDINGS}

\section{Descriptive Results}

Panel A of Figure 1 depicts the variation in the earnings of women and men with partners' modes of financial organization. Panel A1 shows that high earners, particularly women, tended to manage their finances independently of their partners. As a result, the gender gap in partners' relative earnings was smallest among couples who kept separate purses, compared with those who adopted other modes of financial management. This is consistent with Pahl's (1990) and Vogler's (1998) finding that the independent system requires both partners to be economically self-sufficient. In line with the traditional male-breadwinning and male-headed model of the household (Pahl, 1995), men were seen to manage the couple's earnings when their female partners had low individual earnings and made a relatively small contribution to the couple's income. On average, women who managed their own earnings independently earned nearly twice as much as their counterparts from families in which men managed the 
couple’s earnings (£2,151 vs. £1,187). Panel A2 shows that as women earned less and their male partners earned more, control over household financial decisions shifted from females to males, via joint control. Similarly, the gender gap in relative earnings was wider when men rather than women controlled their households' financial decisions.

\section{[Insert Figure 1 Here]}

Panel B of Figure 1 depicts partners' modes of financial organization across the quartile rank of relative earnings. The pooling system was consistently adopted by nearly half of women and men across the distribution of relative earnings. It is worth noting that a sizable number of couples adopted the female whole-wage system even when the female partners' relative earnings were low $\left(19.8 \%\right.$ of women in the $1^{\text {st }}$ quartile and $20.6 \%$ of men in $4^{\text {th }}$ quartile of relative earnings); and a not-small proportion of couples adopted the male whole-wage system even when the female partners' relative earnings were relatively high ( $9.1 \%$ of women in $4^{\text {th }}$ quartile and $9.1 \%$ of men in $1^{\text {st }}$ quartile of relative earnings). Panel B2 shows that the majority of couples made joint financial decisions, irrespective of relative earnings. There was a positive association between relative earnings and control of household financial decisions (Spearman's $r_{\text {women }}=0.20, r_{\text {men }}=0.19$ ). Despite their low level of contribution to the couple's income, $8.7 \%$ of women and $10.5 \%$ of men from the bottom quartile of relative earnings still controlled the couple's financial decisions.

As depicted in Panel C of Figure 1, women spent considerably more time on housework than their male partners across all modes of financial organization. Specifically, as depicted in Panel C1, women's housework time varied little across the pooling $(M=$ 14.47), female whole-wage $(M=14.46)$, and male whole-wage $(M=14.42)$ systems of financial management. In contrast, consistent with autonomy theory (Gupta, 2006, 2007; Bennett, 2013), women who managed their earnings independently spent less time on housework $(M=11.38)$. Panel $\mathrm{C} 2$ shows that for women and men alike, housework time was 
negatively associated with control of household financial decisions. Compared with women who controlled household financial decisions $(M=13.85)$, women whose male partners controlled such decisions spent more time on housework $(M=15.23)$. Men spent less time on housework when they controlled household financial decisions $(M=5.41)$, compared with when their female partners controlled these decisions $(M=6.96)$.

\section{Multivariate Results}

Table 2 presents the estimates from the 2SLS regressions. The results of the Anderson CCLR test for under-identification confirmed the relevance of the IVs, as the $\chi^{2}$ indices were sizable and statistically significant at the $0.1 \%$ level. The Cragg-Donald test for weak instruments also showed that the IVs strongly identified the models, as the $F$-values were well above the Stock-Yoko threshold of 13.97 for three IVs (Stock \& Yogo, 2005). The Hansen-Sargan over-identification test determines if at least one of the IVs is correlated with the error term (Bollen, 2012). As the $\chi^{2}$ indices were small and not statistically significant at the $10 \%$ level, the results did not reject the null hypothesis that the IVs were uncorrelated with the error term.

\section{[Insert Table 2 Here]}

In keeping with previous research, the results of Models $1 \mathrm{~A}$ and $1 \mathrm{~B}$ showed that women's housework time was influenced predominantly by their individual earnings rather than their relative earnings (Gupta, 2006, 2007; Killewald, 2011; Carlson \& Lynch, 2017), whereas relative earnings rather than individual earnings were primarily responsible for shaping men's housework time (Bittman et al., 2003; Brines, 1994; Kan, 2008). The model fit indices showed that the inclusion of financial organization measures improved the overall model fit for both women (log-likelihood $\left.\chi^{2}(5)=23.79, p<.001\right)$ and men (log-likelihood $\left.\chi^{2}(5)=24.30, p<.001\right)$, over and above individual and relative earnings. The results thus 
highlighted the role played by intra-household financial organization in directly shaping the housework time of both women and men.

For the main effects of household financial management, Hypothesis 2A (gendered resources theory) instead of $1 \mathrm{~A}$ (resource bargaining theory) was supported: compared with couples who jointly managed the household finances, both women ( -1.21 hours per week) and men $(-0.54$ hours per week) spent less time on housework when their partners managed the couple's earnings. This is consistent with Pahl's (1990) argument that the management of household finances often represents a time-consuming chore and may be associated with other housekeeping responsibilities. Hypothesis 3A, derived from autonomy theory, was partly supported, as women who managed their earnings independently spent 0.72 hours less on housework per week than those who jointly managed household finances with their partners.

For the main effects of household financial decision making, the results lent partial support to Hypothesis 1B: compared with couples who made joint financial decisions, men in control of financial decisions spent 0.44 hours less on housework per week; and men spent 0.61 hours more on housework per week when their partners controlled these decisions. However, the association between financial decision making and housework time was not statistically significant for women at the $5 \%$ level.

\section{[Insert Table 3 Here]}

Panel A of Table 3 presents the variation in the impact of earnings on housework time with the mode of financial management. Supporting Hypothesis 3B derived from autonomy theory, the results of Model 2A showed that women's individual earnings reduced their housework time when they had partial (i.e., pooling system, $B=-2.28, p<.05$ ) or full access (i.e., female whole-wage system, $B=-2.74, p<.05$; independent system, $B=-2.67, p<.05$ ) to these earnings, but not when their male partners managed all of the couple's earnings $(B=$ 
$-1.29, n s)$. The findings thus confirmed the implicit yet untested premise of autonomy theory: that women's derivation of autonomous power from their earnings is conditional on their capability to access these earnings.

The results of Model 2B supported both Hypothesis 1C (resource bargaining theory) and Hypothesis 2B (gendered resources theory): men's relative earnings were associated with a reduction in their housework time when they managed part (i.e., pooling system, $B=-6.27$, $p<.01$ ) or all (i.e., male whole-wage system, $B=-8.64, p<.001$ ) of the couple's earnings as well as when they handed over their earnings to their partners (i.e., female whole-wage system, $B=-9.18, p<.001)$. These results suggested that men rely on both control-oriented bargaining and cooperation-oriented gender specialization to derive power from relative earnings. Unsurprisingly, given that both resource bargaining theory and gendered resources theory are predicated on the assumption of social exchange between partners (Blood \& Wolfe, 1960; Zuo \& Bian, 2001), relative earnings played little role in shaping men's housework time when partners kept separate purses (i.e., independent system, $B=-1.82, n s$ ).

Panel B of Table 3 shows the variation in the influence of earnings on housework time with the mode of household financial decision making. As shown in Model 3A, Hypothesis 3C derived from autonomy theory was supported, as the negative impact of women's individual earnings on their housework time was particularly strong when the women controlled the families' financial decisions $(B=-3.48, p<.05)$. This impact decreased in size while remaining statistically significant when partners had joint control of the families' financial decisions $(B=-2.26, p<.001)$, but reduced further in size and became statistically non-significant when the male partners controlled these decisions $(B=-1.30, n s)$. Supporting Hypothesis 1D developed from resource bargaining theory, the results of Model 3B showed that men's relative earnings reduced their housework time when they had full $(B$ $=-7.96, p<.01)$ or partial $(B=-7.00, p<.001)$ control of household financial decisions, but 
not when their female partners controlled these decisions $(B=-5.50, n s)$. These findings suggest that control of money plays an important role in shaping the influence of earnings on the housework time of both women and men.

\section{Sensitivity Analysis}

A wide range of sensitivity tests based on alternative samples, measurement codings, and model specifications and with additional control variables were conducted to ensure the robustness of the results. First, more restrictive samples in which both partners were aged between 25 and 54 and engaged in paid work were analyzed, yielding consistent results. Second, for the financial management measure, it was not clear what exact proportion of earnings each partner contributed to the joint pool when the response "we pool some of the money and keep the rest separate" was recorded. However, the positioning of this option close to "we keep our finances completely separate" and distant from "we share and manage our household finances jointly" means that it may have been understood by the survey respondents to denote a high level of independence between partners. This was confirmed through additional analysis: the results reported in this article were robust to the exclusion of the above option from the "independent system" of financial management. Third, the results for the interactions between earnings and the financial organization measures were robust to fitting main-effects models by subsamples separated by the mode of financial management and financial decision making, respectively. Fourth, I experimented with controlling for additional covariates such as migration status, migrant generation, and religious affiliation. As these variables were collinear with ethnicity and gender ideology, they were excluded from the final analysis.

\section{DISCUSSION}

Despite the increase in women's labor force participation and progress toward gender equality in the public sphere over the last several decades, gender inequality in the domestic 
sphere persists in many countries (Altintas \& Sullivan, 2016; Hu \& Yucel, 2018). A long tradition of scholarship focused on the role played by economic resources in configuring marital power (Blood \& Wolfe, 1960; Brines, 1994; Gupta, 2007; Rodman, 1972). As marital power is crucial to the negotiation of housework performance in couple relationships, resource theories have fertilized sustained scholarly efforts to examine the relationship between money and gendered housework (Bittman et al., 2003; Brines, 1994; Carlson \& Lynch, 2017; Chesley \& Flood, 2017; Gupta, 2006, 2007; Killewald, 2011).

Nevertheless, such efforts have suffered from a major limitation: money has been conceptualized and operationalized as a unidimensional construct in terms of earnings (Bittman et al., 2003; Brines, 1994; Carlson \& Lynch, 2017; Gupta, 2006, 2007; Kan, 2008; Killewald \& Gough, 2010; Killewald, 2011; Usdansky \& Parker, 2011). Although much has been written about the intra-household economy and its inequalities in couple relationships (Bennett, 2013; Himmelweit et al., 2013; Pahl, 1989, 1990, 1995; Pepin, 2019; Vogler, 1998, 2005), we still know little about whether and how the distribution, management, and control of one's own and the couple's earnings shape the gendered housework participation of women and men. Seeking to fill this gap, this research re-examined the relationship between money and housework by interrogating the role played by household financial organization in shaping the housework time of women and men and in moderating the influence of earnings on housework.

The results showed that the organization of household finances is both distinct from and as important as the generation of earnings in shaping conjugal power, in that financial organization had a net impact on housework time. Although scholars have long emphasized the multifaceted nature of intra-household finances (Pahl, 1989, 1995; Vogler, 1998, 2005; Bennett, 2013), it was unclear whether and how distinct aspects of financial organization may entail different consequences for conjugal power. This research remedies this important gap 
by distinguishing the roles played by financial management and financial decision making in shaping partners' housework time. On the one hand, in line with Pahl's argument (1990, 1995) that everyday financial management represents an onerous chore in itself and often correlates with involvement in other housekeeping tasks, both women and men spent less time on housework when their partners managed household finances. Supporting autonomy theory, however, women's management of their own rather than the couple's earnings reduced the time they spent on housework. On the other hand, men's control of household financial decisions reduced the time they spent on housework. As high-earning women were more likely to take control of household financial decisions than their low-earning counterparts, the absence of a statistically significant link between control of financial decisions and women's housework time may have been due to the correlation between women's control of financial decisions and their earnings.

The findings also showed that resource generation in the labor market and resource organization in the household operated jointly rather than separately in constructing conjugal power. Financial management can be an onerous chore in itself and one partner may not be able to directly derive power from managing the couple's earnings. Nevertheless, managing the household's finances may indirectly enable individuals to derive relative or autonomous power from the money they manage to negotiate their housework participation. Extending existing resource theories (Becker, 1991; Blood \& Wolfe, 1960; Brines, 1994; Chesley \& Flood, 2016; Gupta, 2007; Rodman, 1972), I found distinct intra-gender mechanisms that power around financial organization interacts with relative earnings in shaping the housework time of men, yet it interacts with individual earnings in shaping that of women. Conjugal power is not merely the result of individual characteristics and intra-household dynamics (Yodanis \& Lauer, 2007), it is also embedded in broader social and institutional contexts (Cherlin, 2010). The findings imply a tale of two genders in the evolvement of couple 
relationships in the UK. Whereas men hold onto a communal model of family as they derive power from resource monopolization or exchange predicated on relative earnings (Cherlin, 2010), women tend to benefit from an individualized model of couplehood as they derive power from mobilizing their individual resources (Beck \& Beck-Gernsheim, 2002).

The findings more specifically reflect on the mechanisms underpinning the social exchange and resource theories of marital power and gendered housework participation. The salience of relative earnings to the generation of marital power and housework performance is largely predicated on the exchange relationships between partners in unitary couple units (Blood \& Wolfe, 1960; Becker, 1991). However, this premise has generally been assumed rather than empirically tested. Earnings provide only a roundabout proxy of resource dependence between partners. I have demonstrated that the analysis of financial organization provides direct evidence of the behavioral enactment of exchange or its lack in couple relationships. My findings show that the role of relative earnings in shaping men's housework time is conditional on the literal transfer or sharing of earnings between partners.

The observation that men who contribute a larger share to the couple's earnings spend less time on housework is not new (Bittman et al., 2003; Brines, 1994; Carlson \& Lynch, 2017; Kan, 2008). However, explanations of this observation are less conclusive. As the theories of resource bargaining and gendered resources similarly predict that relative earnings reduce one's housework time (Becker, 1991; Blood \& Wolfe, 1960; Tichenor, 1999; Zuo \& Bian, 2001), the two theories have seldom been empirically distinguished in prior research, despite their substantively different mechanisms of operation. In this research, the analysis of household financial management made it possible to disentangle the two theories by tracing the distinct directions in which money flowed between partners. I discovered that both theories were operative, instead of just one or the other. Consistent with resource bargaining theory (Becker, 1991; Blood \& Wolfe, 1960; Rodman, 1972), men’s relative earnings helped 
them to "bargain out" of housework when they managed the couple's earnings. Supporting gendered resources theory (Tichenor, 1999; Zuo \& Bian, 2001), men's relative earnings also helped them to "exchange out" of housework by handing over the management of the couple's earnings to their female partners.

Shedding new light on previously untested premises of autonomy theory, the findings also challenge the taken-for-granted assumption that individual earnings may readily confer marital power and automatically enable women to "opt out" or "buy out" of housework (Gupta, 2006, 2007; Killewald \& Gough, 2010; Killewald, 2011). Existing theories have underlined the importance of individual resources in bolstering marital power and thus reducing housework time, particularly for women (Gupta, 2006; Usdansky \& Parker, 2011). However, my findings clearly show that individual earnings obtained from paid work are only the starting point for women's development of individual autonomy. I have demonstrated that to "opt out" or "buy out" of housework, it is insufficient for women to merely participate in paid work. Rather, they also need to be able to access their earnings (through financial management) and control these earnings (by influencing financial decisions). Killewald and Gough (2010, p. 997) found that in the US, individual earnings had a stronger negative association with housework time among women with lower earnings. They explained that individual earnings may not lead to a reduction in housework time among high-earning women, because "they have already stopped performing household tasks that are the easiest and cheapest to outsource or forego." However, my findings suggest that low-earning women in the UK, who are expected to benefit most from their individual earnings (cf. Killewald \& Gough, 2010), are often prevented from translating these earnings into a reduction in housework time by a lack of access to and control of their earnings.

The limitations of this research suggest a few cautions in interpreting the results and important directions for future work. I did not examine gender display theory or gender- 
deviance neutralization theory, because reliable estimates were not attainable with the inclusion of an endogenous quadratic term for relative earnings in the 2SLS models (cf. Carlson \& Lynch, 2017). The strength of the 2SLS approach hinges on assumptions such as correct model specification and adequacy of IVs (Bollen, 2012). For example, biased estimation may arise from unobserved variables and misspecification of time lags (Carlson \& Lynch, 2017). The reliability of results from 2SLS models are also susceptible to the correlation between IVs and equation error terms and weak IVs (Bollen, 2012). Although the appropriateness of my IV and model choices were informed by theory and supported by statistical tests, scholars could usefully replicate the analysis and verify the findings using new instruments and datasets. Although the reliability of stylized time-use measures in the UKHLS is substantiated by both prior research (Kan \& Pudney, 2008) and comparison with time-diary data (Altintas \& Sullivan, 2016), it would be particularly beneficial to collect and analyze time-diary data alongside measures of household finances, which will provide more fine-grained insights into the temporal dynamics of housework, for example, on work vis-àvis nonwork days (Chesley \& Flood, 2017).

The analysis was necessarily limited to a two-wave framework, because the measure of household financial management was included only in Wave 4 and the measures of housework time and gender ideology were included only in Waves 2 and 4 of the UKHLS to date. Going forward, it will be crucial to collect comparable and regular waves of data on household financial organization to enable fuller longitudinal analysis. Such analysis will also benefit from a larger sample size and a richer set of measures of household finances. Due to cell-size constraints, I was unable to test the interaction between financial management and financial decision making or the three-way interaction of earnings, financial management, and financial decision making. Future researchers are encouraged to consider whether financial management and decision making operate in conjunction, rather than in isolation, in 
shaping the influence of earnings on conjugal power. Although this research focused on the intra-household flow, management, and control of income in the UK, future efforts should be made to extend this focus to include savings, assets, and human capital (Bennett, 2013; Sullivan \& Gershuny, 2016) and take account of variation in intra-household dynamics across different institutional and social contexts (Yodanis \& Lauer, 2007).

Despite its limitations, however, the research clearly demonstrates the need to move beyond wage and earnings to explore the important role played by intra-household financial organization in the relationship between money and marital power. As complex social processes such as financial management and decision making intervene in the relationship between earnings and housework, these processes present potential "barriers" to the translation of women's labor force participation and market earnings into gender equality at home. Therefore, scholars and policy-makers are encouraged to consider money as a plural concept and take account of the ways in which household financial organization confers, distributes, and (re)balances power between partners (Bennett, 2013). To "unstall" the domestic gender revolution, this research refines resource theories by uncovering distinct intra-gender mechanisms underpinning the nuanced interactions between earnings, household finances and marital power for women and men. Nonetheless, the existence of a sizable residual gender gap in housework time also calls for continued efforts to go beyond the resource perspective in order to complete the domestic gender revolution.

\section{REFERENCES}

Altintas, E., \& Sullivan, O. (2016). Fifty years of change updated: Cross-national gender convergence in housework. Demographic Research, 35, 455-470.

https://doi.org/10.4054/DemRes.2016.35.16

Ashby, K. J., \& Burgoyne, C. B. (2009). The financial practices and perceptions behind separate systems of household financial management. The Journal of Socio- 
Economics, 38(3), 519-529. https://doi.org/10.1016/j.socec.2009.02.007

Baum, C.F., Schaffer, M.E., \& Stillman, S. (2010). ivreg2: Stata module for extended instrumental variables/2SLS, GMM and AC/HAC, LIML and k-class regression. http://ideas.repec.org/c/boc/bocode/s425401.html

Beck, U., \& Beck-Gernsheim, E. (2002). Individualization: Institutionalized individualism and its social and political consequences. London: Sage.

Becker, G. S. (1991). A treatise on the family. Cambridge, MA: Harvard University Press.

Bennett, F. (2013). Researching within-household distribution: Overview, developments, debates and methodological challenges. Journal of Marriage and Family, 75(3), 582597. https://doi.org/10.1111/jomf.12020

Bianchi, S. M., Sayer, L. C., Milkie, M. A., \& Robinson, J. P. (2012). Housework: Who did, does or will do it, and how much does it matter? Social Forces, 91(1), 55-63. https://doi.org/10.1093/sf/sos120

Bisdee, D., Daly, T., \& Price, D. (2013). Behind closed doors: Older couples and the gendered management of household money. Social Policy and Society, 12(1), 163-174. https://doi.org/10.1017/S147474641200053X

Bittman, M., England, P., Sayer, L., Folbre, N., \& Matheson, G. (2003). When does gender trump money? Bargaining and time in household work. American Journal of Sociology, 109(1), 186-214. https://doi.org/10.1086/378341

Blood, R. O., Jr., \& Wolfe, D. M. (1960). Husbands and wives: The dynamics of married living. New York: New York Press.

Brines, J. (1994). Economic dependency, gender, and the division of labor at home. American Journal of Sociology, 100(3), 652-688. https://doi.org/10.1086/230577

Bollen, K. A. (2012). Instrumental variables in sociology and the social sciences. Annual Review of Sociology, 38, 37-72. https://doi.org/10.1146/annurev-soc-081309-150141 
Carlson, D. L., \& Lynch, J. L. (2013). Housework: Cause and consequence of gender ideology? Social Science Research, 42(6), 1505-1518. https://doi.org/10.1016/j.ssresearch.2013.07.003

Carlson, D. L., \& Lynch, J. L. (2017). Purchases, penalties, and power: The relationship between earnings and housework. Journal of Marriage and Family, 79(1), 199-224. https://doi.org/10.1111/jomf.12337

Cherlin, A. J. (2010). The marriage-go-around: The state of marriage and the family in America today. New York: Alfred A. Knopf.

Chesley, N., \& Flood, S. (2017). Signs of change? At-home and breadwinner parents' housework and child-care time. Journal of Marriage and Family, 79(2), 511-534. https://doi.org/10.1111/jomf.12376

Cooke, L. P., \& Hook, J. L. (2018). Productivity or gender? The impact of domestic tasks across the wage distribution. Journal of Marriage and Family, 80(3), 721-736. https://doi.org/10.1111/jomf.12467

Cunningham, M. (2001a). Parental influences on the gendered division of housework. American Sociological Review, 66(2), 184-203. http://www.jstor.org/stable/2657414

Cunningham, M. (2001b). The influence of parental attitudes and behaviors on children's attitudes toward gender and household labor in early adulthood. Journal of Marriage and family, 63(1), 111-122. https://doi.org/10.1111/j.1741-3737.2001.00111.x

Davis, S. N., \& Greenstein, T. N. (2013). Why study housework? Cleaning as a window into power in couples. Journal of Family Theory \& Review, 5(2), 63-71. https://doi.org/10.1111/jftr.12004

England, P. (2010). The gender revolution: Uneven and stalled. Gender \& Society, 24(2), 149-166. https://doi.org/10.1177/0891243210361475 
Gerson, K. (2009). The unfinished revolution: Coming of age in a new era of gender, work, and family. New York: Oxford University Press.

Gupta, S. (2006). Her money, her time: Women's earnings and their housework hours. Social Science Research, 35(4), 975-999. https://doi.org/10.1016/j.ssresearch.2005.07.003

Gupta, S. (2007). Autonomy, dependence, or display? The relationship between married women's earnings and housework. Journal of Marriage and Family. 69(2), 399-417. https://doi.org/10.1111/j.1741-3737.2007.00373.x

Himmelweit, S., Santos, C., Sevilla, A., \& Sofer. C. (2013). Sharing of resources within the family and the economics of household decision making. Journal of Marriage and Family, 75(3), 625-639. https://doi.org/10.1111/jomf.12032

Hu, Y., \& Yucel, D. (2018). What fairness? Gendered division of housework and family life satisfaction across 30 countries. European Sociological Review, 34(1), 92-105. https://doi.org/10.1093/esr/jcx085

Kan, M. Y. (2008). Does gender trump money? Housework hours of husbands and wives in Britain. Work, Employment \& Society, 22(1), 45-66. https://doi.org/10.1177/0950017007087416

Kan, M. Y., \& Pudney, S. (2008). Measurement error in stylized and diary data on time use. Sociological Methodology, 38(1), 101-132. https://doi.org/10.1111/j.14679531.2008.00197.

Kan, M. Y., \& Laurie, H. (2018). Who is doing the housework in multicultural Britain? Sociology, 52(1), 55-74. https://doi.org/10.1177/0038038516674674

Kenney, C. T. (2006). The power of the purse: Allocative systems and inequality in couple households. Gender \& Society, 20(3), 354-381. https://doi.org/10.1177/0891243206286742

Killewald, A., \& Gough, M. (2010). Money isn’t everything: Wives' earnings and housework 
time. Social Science Research, 39(6), 987-1003.

https://doi.org/10.1016/j.ssresearch.2010.08.005

Killewald, A. (2011). Opting out and buying out: Wives' earnings and housework time. Journal of Marriage and Family, 73(2), 459-471. https://doi.org/10.1111/j.17413737.2010.00818.x

Knies, G. (Ed.) (2016). Understanding Society-UK Household Longitudinal Study: Wave 16, 2009-2015, user manual. Colchester: University of Essex.

Li, C. (2013). Little's test of missing completely at random. Stata Journal, 13(4), 795-809. https://doi.org/10.1177/1536867X1301300407

Lundberg, S., \& Pollak, R. (1996). Bargaining and distribution in marriage. The Journal of Economic Perspectives, 10(4), 139-158. https://doi.org/10.1257/jep.10.4.139

Pahl, J. (1989). Money and marriage. Houndmills, UK: Macmillan Education.

Pahl, J. (1990). Household spending, personal spending, and the control of money in marriage. Sociology, 24(1), 119-138. https://doi.org/10.1177/0038038590024001009

Pahl, J. (1995). His money, her money: Recent research on financial organisation in marriage. Journal of Economic Psychology, 16(3), 361-376. https://doi.org/10.1016/0167-4870(95)00015-G

Pepin, J. R. (2019). Beliefs about money in families: Balancing unity, autonomy, and gender equality. Journal of Marriage and Family. E-pub ahead of print: https://doi.org/10.1111/jomf.12554

Rodman, H. (1972). Marital power and the theory of resources in cultural context. Journal of Comparative Family Studies, 3(1), 50-69. https://www.jstor.org/stable/41600800

Scott, J. L., Crompton, R., \& Lyonette, C. (2010). Gender inequalities in the $21^{\text {st }}$ century: New barriers and continuing constraints. Cheltenham: Edward Elgar.

Stock J, \& Yogo, M. (2005). Testing for weak instruments in linear IV regression. In D. W. 
K. Andrews (Ed.), Identification and inference for econometric models (pp. 80-108). New York: Cambridge University Press.

Sullivan, O., \& Gershuny, J. (2016). Change in spousal human capital and housework: A longitudinal analysis. European Sociological Review, 32(6), 864880. https://doi.org/10.1093/esr/jcw043

Tichenor, V. J. (1999). Status and income as gendered resources: The case of marital power. Journal of Marriage and the Family, 61(3), 638-650. https://doi.org/10.2307/353566

Usdansky, M. L., \& Parker, W. M. (2011). How money matters: College, motherhood, earnings, and wives' housework. Journal of Family Issues, 32(11), 1449-1473. https://doi.org/10.1177/0192513X11402953

Vogler, C. (1998). Money in the household: Some underlying issues of power. The Sociological Review, 46(4), 687-713. https://doi.org/10.1111/1467-954X.00136

Vogler, C. (2005). Cohabiting couples: Rethinking money in the household at the beginning of the twenty first century. The Sociological Review, 53(1), 1-29. https://doi.org/10.1111/j.1467-954X.2005.00501.x

Yodanis, C., \& Lauer, S. (2007). Managing money in marriage: Multilevel and cross-national effects of the breadwinner role. Journal of Marriage and Family, 69(5), 1307-1325. https://doi.org/10.1111/j.1741-3737.2007.00449.X

Zelizer, V. A. (1994). The social meaning of money: Pin money, paychecks, poor relief, and other currencies. New York: Basic Books.

Zuo, J., \& Bian, Y. (2001). Gendered resources, division of housework, and perceived fairness-A case in urban China. Journal of Marriage and Family, 63(4), 1122-1133. https://doi.org/10.1111/j.1741-3737.2001.01122.x 
FIGURE 1. DESCRIPTIVE STATISTICS OF INDIVIDUAL EARNINGS, RELATIVE EARNINGS, HOUSEWORK TIME, AND FINANCIAL ORGANIZATION, BY GENDER

(A) Individual earnings, by mode of financial organization

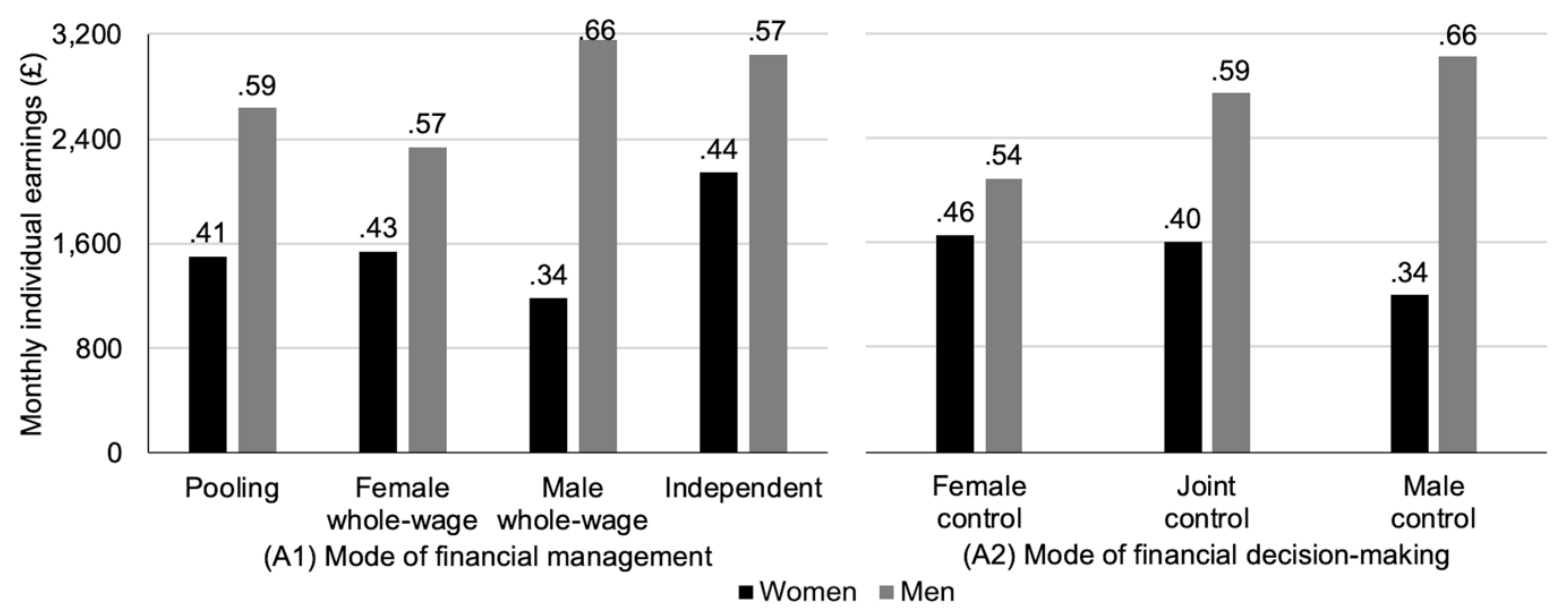

(B) Mode of financial organization, by quartile rank of relative earnings

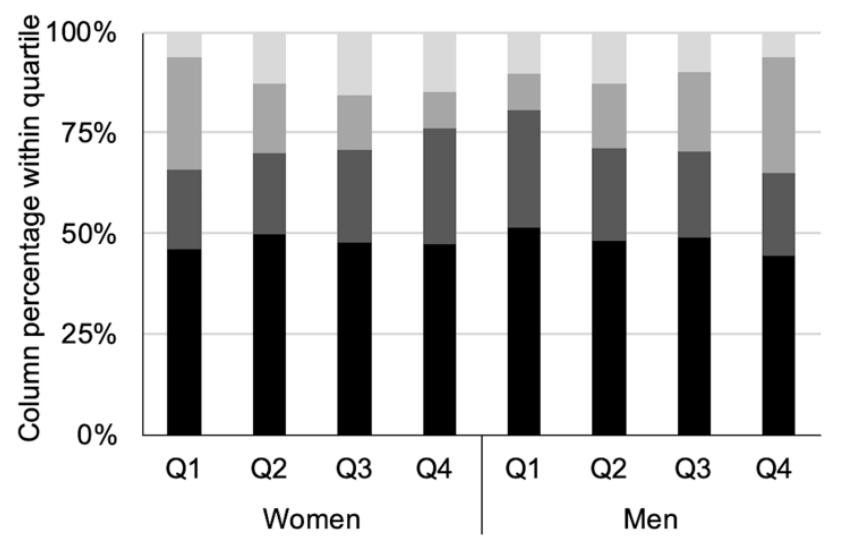

(B1) Relative earnings

- Pooling Female whole-wage

Male whole-wage $\quad$ Independent

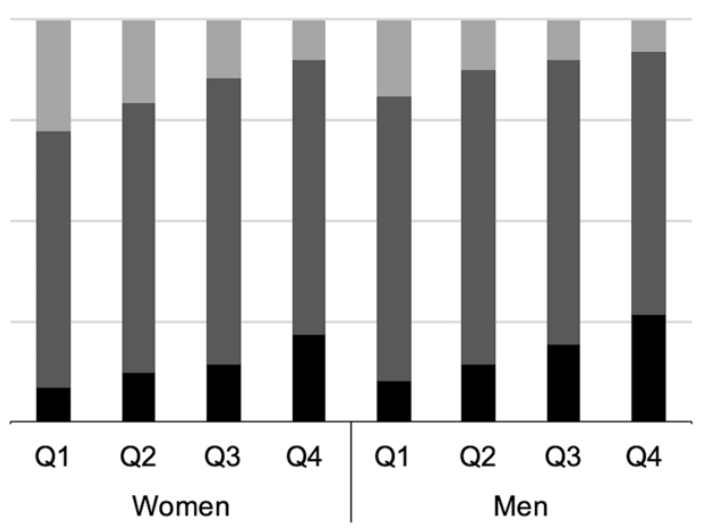

(B2) Relative earnings

- Female control u Joint control - Male control

(C) Housework time, by mode of financial organization

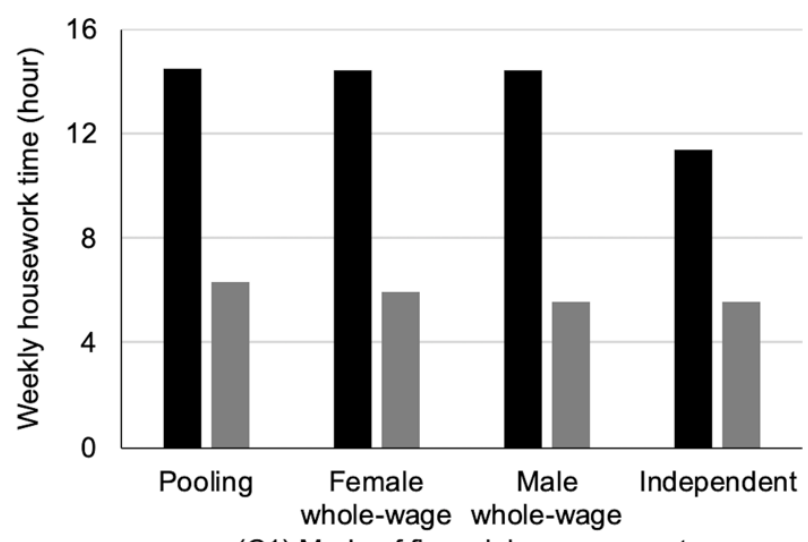

(C1) Mode of financial management

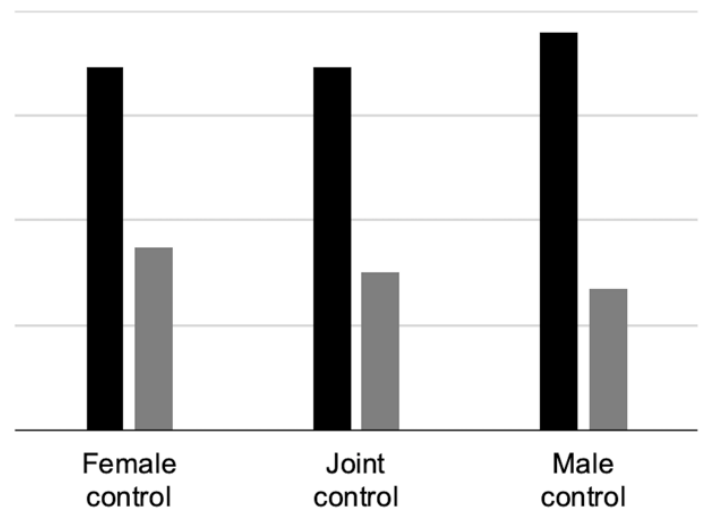

(C2) Mode of financial decision-making

-Women $=$ Men

Note. $N=6,070$ couples. In Panel $\mathrm{B}, N \approx 1,517$ for each equal quartile. Mean values reported in Panels $\mathrm{A}$ and $\mathrm{C}$. In Panel A1, statistics at the end of bars indicate relative earnings. As relative earnings were calculated from the individual reports from women and men respectively, and also due to rounding, the percentages of women's and men's reports may not add up to 1.1 British pound $\approx 1.58$ US dollars in 2013. Weighted statistics. 
Table 1. Sample Characteristics ( $\mathrm{N}=6,070$ couples)

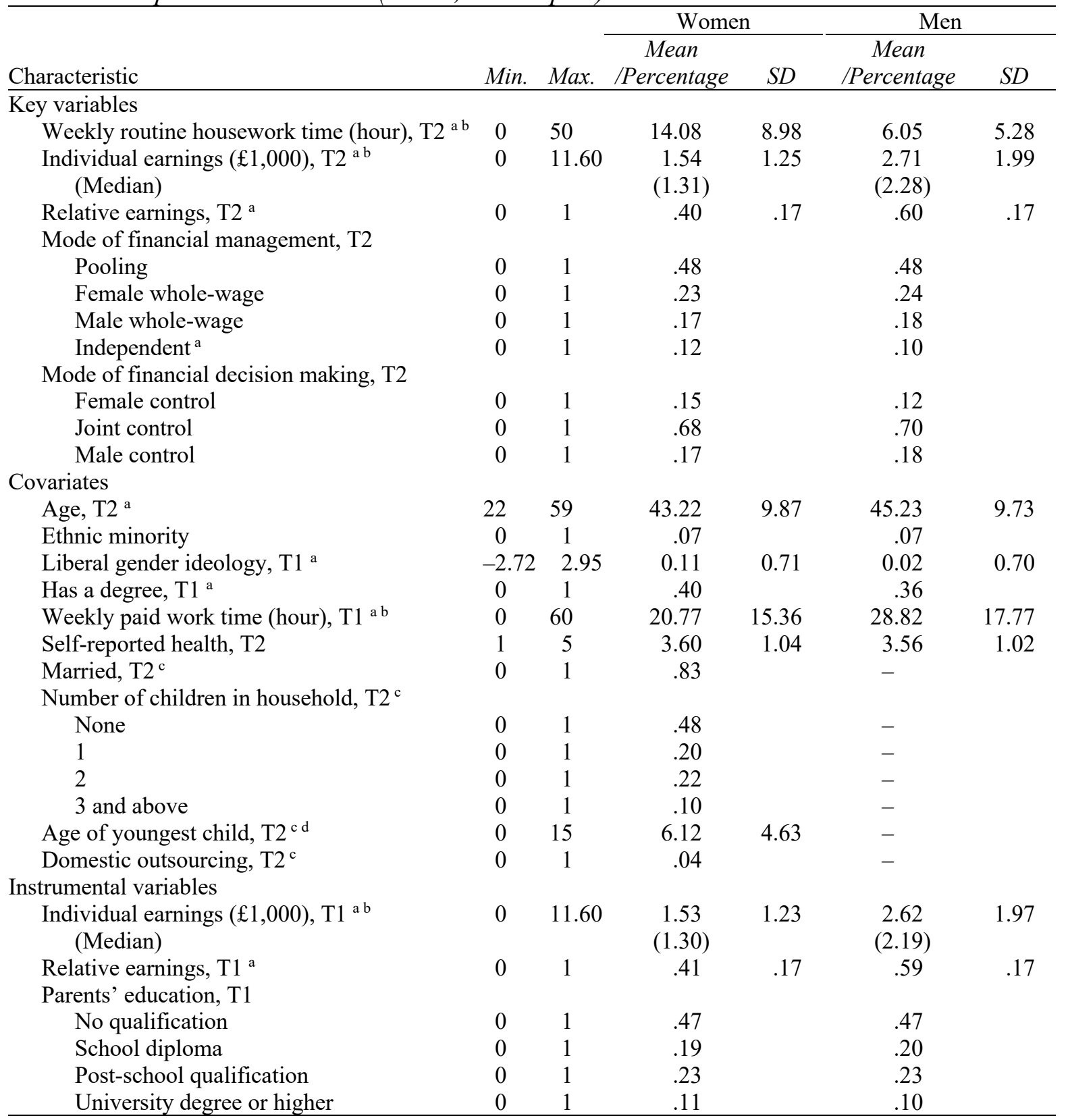

Note. For dummy variables, $0=$ No and $1=$ Yes. $S D=$ standard deviation. Mean values reported for continuous variables and percentages reported for dummy variables. Column percentages may not add up to 1 due to rounding. 1 British sterling pound $\approx 1.58$ US dollars in 2013. Weighted statistics with unweighted sample size. ${ }^{a}$ Gender difference significant at the $1 \%$ level and below, based on two-tailed chi-squared test for categorical variables and $t$-test for continuous variables. ${ }^{\mathrm{b}}$ Top-coded at the $99^{\text {th }}$ percentiles to reduce the influence of outlier cases. ${ }^{\mathrm{c}}$ Couple-level variable. ${ }^{\mathrm{d}}$ Calculated based on families with at least one child in the household. 
Table 2. Two-stage least squares regression models predicting weekly routine housework time of women and men ( $\mathrm{N}=6,070$ couples)

\begin{tabular}{|c|c|c|c|c|}
\hline \multirow[b]{2}{*}{ Predictor } & \multicolumn{2}{|c|}{ 1A: Women } & \multicolumn{2}{|c|}{ 1B: Men } \\
\hline & $B$ & $R S E$ & $B$ & $R S E$ \\
\hline Individual earnings $(\log ), \mathrm{T} 2$ & $-2.29 * * *$ & 0.57 & -0.44 & 0.33 \\
\hline Relative earnings, $\mathrm{T} 2$ & -3.01 & 1.80 & $-6.96 * * *$ & 1.24 \\
\hline \multicolumn{5}{|l|}{ Financial management (ref = pooling), $\mathrm{T} 2$} \\
\hline Female whole-wage & 0.31 & 0.28 & $-0.54 * *$ & 0.17 \\
\hline Male whole-wage & $-1.21 * * *$ & 0.32 & 0.22 & 0.18 \\
\hline Independent & $-0.72 *$ & 0.30 & -0.30 & 0.22 \\
\hline \multicolumn{5}{|l|}{$\begin{array}{l}\text { Financial decision making }(\mathrm{ref}=\text { joint } \\
\text { control), } \mathrm{T} 2\end{array}$} \\
\hline Female control & 0.04 & 0.33 & $0.61 * *$ & 0.23 \\
\hline Male control & 0.26 & 0.31 & $-0.44 *$ & 0.18 \\
\hline Age, T2 & $0.12 * * *$ & 0.01 & $0.05^{* * *}$ & 0.01 \\
\hline Ethnic minority $(\mathrm{ref}=\mathrm{no})$ & $1.22 * *$ & 0.49 & 0.01 & 0.31 \\
\hline Partner ethnic minority $(\mathrm{ref}=\mathrm{no})$ & $1.24 *$ & 0.47 & -0.30 & 0.28 \\
\hline Liberal gender ideology, T1 & $-0.36 *$ & 0.18 & $0.40^{* * *}$ & 0.11 \\
\hline Partner's liberal gender ideology, T1 & $-1.11 * * *$ & 0.17 & 0.17 & 0.11 \\
\hline Has a degree $(\mathrm{ref}=\mathrm{no}), \mathrm{T} 1$ & $-0.78 * *$ & 0.25 & $0.43 * *$ & 0.16 \\
\hline Partner has a degree $(\mathrm{ref}=\mathrm{no}), \mathrm{T} 1$ & $-0.97 * * *$ & 0.25 & 0.30 & 0.16 \\
\hline Weekly paid work time, T1 & $-0.09 * * *$ & 0.01 & -0.00 & 0.00 \\
\hline Partner's weekly paid work time, T1 & -0.01 & 0.01 & 0.01 & 0.01 \\
\hline Self-reported health (high $=$ good), T2 & -0.01 & 0.12 & 0.04 & 0.07 \\
\hline Partner's self-reported health (high $=$ good), T2 & -0.12 & 0.12 & $-0.50 * * *$ & 0.07 \\
\hline Married (ref = cohabiting), T2 & $0.62 *$ & 0.28 & -0.27 & 0.19 \\
\hline \multicolumn{5}{|l|}{$\begin{array}{l}\text { Number of children in household } \\
\text { (ref = none), T2 }\end{array}$} \\
\hline 1 & $2.90 * * *$ & 0.41 & $1.30^{* * *}$ & 0.25 \\
\hline 2 & $4.43 * * *$ & 0.37 & $1.59^{* * *}$ & 0.23 \\
\hline 3 and above & $7.11 * * *$ & 0.49 & $2.35^{* * *}$ & 0.29 \\
\hline Age of youngest child, T2 & -0.07 & 0.04 & $-0.06^{* *}$ & 0.02 \\
\hline Domestic outsourcing $(\mathrm{ref}=\mathrm{no}), \mathrm{T} 2$ & $-2.15 * * *$ & 0.43 & $-0.68 *$ & 0.28 \\
\hline Intercept & $12.75^{* * *}$ & 1.21 & $9.58^{* * *}$ & 0.84 \\
\hline Anderson CCLR $\chi^{2}$ & $868.24 * * *$ & & $871.47 * * *$ & \\
\hline Hansen-Sargan $\chi^{2}$ & 4.16 & & 5.95 & \\
\hline Cragg-Donald Wald $F$ & $432.87 * * *$ & & $419.59 * * *$ & \\
\hline$\chi^{2}$ (financial management) & $23.39 * * *$ & & $14.58 * *$ & \\
\hline$\chi^{2}$ (financial decision making) & 0.77 & & $14.08 * * *$ & \\
\hline$R^{2}$ (without financial organization measures) & .211 & & .077 & \\
\hline$R^{2}$ (full model) & .223 & & .082 & \\
\hline
\end{tabular}

Note. $\mathrm{RSE}=$ robust standard error. $\mathrm{CCLR}=$ canonical correlation likelihood ratio test for under-identification. $\mathrm{T} 1=$ time 1 , wave 2 of the UKHLS. T2 = time 2 , wave 4 of the UKHLS. Weighted statistics.

$* p<.05 ; * * p<.01 ; * * *<.001$ (two-tailed tests). 
Table 3. Two-stage least squares regression models testing the role of financial management and financial decision making in moderating the influence of individual and relative earnings on housework, by gender ( $\mathrm{N}=6,070$ couples)

\begin{tabular}{|c|c|c|c|c|}
\hline \multirow{2}{*}{$\begin{array}{l}\text { Panel A: Moderated by mode of financial } \\
\text { management, } 22\end{array}$} & \multicolumn{2}{|c|}{ 2A: Women } & \multicolumn{2}{|c|}{ 2B: Men } \\
\hline & $B$ & $R S E$ & $B$ & $R S E$ \\
\hline \multicolumn{5}{|l|}{ Individual earnings $(\log ), \mathrm{T} 2$} \\
\hline Pooling & $-2.28 *$ & 0.93 & -0.80 & 0.50 \\
\hline Female whole-wage & $-2.74 *$ & 1.20 & -0.03 & 0.71 \\
\hline Male whole-wage & -1.29 & 1.36 & 0.12 & 0.70 \\
\hline Independent & $-2.67 *$ & 1.14 & -0.93 & 0.93 \\
\hline \multicolumn{5}{|l|}{ Relative earnings, $\mathrm{T} 2$} \\
\hline Pooling & -1.95 & 2.60 & $-6.27 * *$ & 1.91 \\
\hline Female whole-wage & -2.56 & 3.71 & $-8.64 * * *$ & 2.39 \\
\hline Male whole-wage & -4.70 & 5.09 & $-9.18 * *$ & 2.86 \\
\hline Independent & -4.99 & 4.23 & -1.82 & 3.49 \\
\hline \multirow{2}{*}{$\begin{array}{l}\text { Panel B: Moderated by mode of financial } \\
\text { decision making, } \mathrm{T} 2\end{array}$} & \multicolumn{2}{|c|}{ 3A: Women } & \multicolumn{2}{|c|}{ 3B: Men } \\
\hline & $B$ & $R S E$ & $B$ & $R S E$ \\
\hline \multicolumn{5}{|l|}{ Individual earnings $(\log ), \mathrm{T} 2$} \\
\hline Female control & $-3.48 *$ & 1.54 & -1.49 & 1.11 \\
\hline Joint control & $-2.26 * * *$ & 0.67 & -0.36 & 0.39 \\
\hline Male control & -1.30 & 1.51 & -0.00 & 0.73 \\
\hline \multicolumn{5}{|l|}{ Relative earnings, $\mathrm{T} 2$} \\
\hline Female control & -1.50 & 5.12 & -5.50 & 3.79 \\
\hline Joint control & -2.35 & 2.09 & $-7.00 * * *$ & 1.43 \\
\hline Male control & -5.73 & 4.66 & $-7.96 * *$ & 3.06 \\
\hline
\end{tabular}

Note. RSE $=$ robust standard error. T2 $=$ time 2 , wave 4 of the UKHLS. Models included all other variables reported in Table 2 - the results of which changed little from those reported in Table 2. Weighted statistics. $* p<.05 ; * * p<.01 ; * * * p<.001$ (two-tailed tests). 